\title{
COMMUNITY NURSING CARE FOR THE MENTALLY RETARDED
}

\author{
Cynthia D. Reingold
}

Sister, Alexander Care and Rehabilitation Centre, Maitland.

\section{OPSOMMING}

Die mees doeltreffende sorg vir die geestesvertraagde is die omvattende gesinsgeoriënteerde sorg van die multidisiplinêre span.

As lid van hierdie span is die gemeenskapsverpleegkundige besig met die voorkoming van geestesvertraagdheid en die bevordering van normalisering deur stimulering van gemeenskapsbetrokkenheid en die hantering van individuele gevalle.

Die oogmerk van gemeenskapsverpleegkunde is die daarstelling van 'n gelukkige en gesonde gesinsomgewing vir die geestesvertraagde in die gemeenskap en die rehabilitasie van geinstitusionaliseerde geestesvertraagdes in die gemeenskapslewe.

Community care for the mentally retarded takes cognisance of the many facets of care required and available for the mentally retarded.

Community care may be regarded as care provided by the general public for the mentally retarded in their midst as well as care provided by the professionals, particularly health and teaching professions, for the mentally retarded in the community.

Tasks of the Community Nurse are:-

- Co-ordination of services for the mentally retarded

- Education of public and professionals

- Assessment and planning

- Counselling and support

- Training and rehabilitation of the mentally retarded for community living

- Placement in the community and supervision.

In order to facilitate the aforementioned optimum care the nurse functions as a member of a multidisciplinary team, which includes a psychologist, psychiatrist, social worker, occupational therapist, physiotherapist and teacher.

At times this team may include other professionals in the community e.g. health visitor, general practitioner, outside social welfare agency, minister of religion, etc.

The multidisciplinary team approach is currently viewed as the only way of providing all the requirements for the mentally retarded. Two influential reports point towards such an approach:-

- The Report of the Committee on Child Health Services (England, 1976)(1) and

- Special Educational Needs - Report of the Committee of Enquiry into the Education of Handicapped Children and Young People, 1978. (2)
The aim of the multidisciplinary team is to provide support in order that the mentally retarded and his family may live a full and happy life.

"Albert Kushlick recognised that parents provide the best caring service for mentally retarded children" (3)

Parents can give the child love, bonding and socialisation experiences, especially teaching them the norms and values of society, which cannot be learnt in an institution.

This defines the community nurse's task further, into one which aims at keeping the mentally retarded child in his home environment with as little time as possible spent in institutions.

Years of institutionalisation and custodial care have left a legacy of persons whom the nurse, today, must rehabilitate into family life and the community.

The daily discovery of clients of all ages, in the community, whose training and education have been neglected, is yet another area in which the nurse is active in rehabilitation.

THE NURSE'S ROLE REGARDING THE PREVENTION OF MENTAL RETARDATION AND PROMOTING OF CARE FOR THE MENTALLY RETARDED BY THE COMMUNITY

1. As with all health problems prevention is better than cure and the nurse must educate and guide the community in this regard.

The authorities and the general public, particularly potential parents, need to be made aware of the medical and psyco-social factors which can increase the incidence of mental retardation. Alcoholism in the mother and malnutrition of the infant are but two high risk medical conditions.

Social stress e.g. poor housing, insufficient income, may cause emotional problems in the family 
resulting in rejection, emotional deprivation and mental and physical abuse, any of which may contribute to mental retardation.

\section{PROMOTION OF NORMALISATION}

The nurse's task in this respect is directed towards the:

(a) Acceptance by the Community of the mentally retarded so that they may, within their potential, enjoy the rights accorded to others.

The first and most important group is the parents of the newly born retarded child. The immediate effects of this trauma are feelings of shock, disbelief and grief. The nurse must be aware of this and give immediate support.

The support is firstly to disclose the problem to, ideally, both parents simultaneously and as soon after birth as possible. "The parents should be informed, whether or not they have asked"' (4)

The approach must be neither cold and clinical nor casual and unrealistic and the door must be kept open for further discussion, as parents are unable to accept and understand the full implications immediately.

Once the parents feel that they are not alone in the world to carry this heavy burden and that people with knowledge, empathy and willingness to help are at hand, they can begin to accept this child and the all important bonding with the mother is assured.

If the parents' towards the mentally retarded child is a positive one, the siblings will adopt this same attitude and generally the extended family are able to do so too.

The community beyond that of the family is the next group requiring education and enlightenment in respect of mental retardation. The nurse has frequent opportunities, both in her professional and social life to dispel misconceptions about mental retardation, to make known their rights, their potentials and their abilities.

Acceptance by the general public is essential for facilitating normalisation. Public rejection is so often a major deterrent, preventing families from keeping their mentally retarded at home. Public acceptance gives the mentally retarded easier access to community facilities, especially accommodation and work.

The public can also be motivated to provide funds for special facilities such as schools, recreation clubs, playgrounds etc.

The provision of opportunities for social contact with normal persons, both for the mentally retarded at home and in institutions can only be provided by the general public.

As social skills are the most important requirements for normalisation, the importance of family and community involvement cannot be over emphasised. (b) Mobilisation of the Community

The nurse must familiarise herself with the community and make herself known to them. She must work with the community, not for them, or they for her. A pleasant personality and appearance go a long way to "sell" mental retardation to the public.

The needs of the mentally retarded and their families must be assessed. The type of assistance given will depend on what these individuals find the most acceptable and feasible.

Priority needs must be established, and short, medium and long term goals planned.

Resources in the community need to be identified. These might be existing service clubs and organisations, student groups, parents of retardates etc. There might be existing facilities in the community which can be used for the mentally retarded or where the mentally retarded can participate in the activities of normal people e.g. coffee mornings for the aged, horse riding schools, public swimming pools, seaside camps.

The support of community leaders, e.g. city councillors, school principals, clergymen, etc. can stimulate projects aimed at normalisation for the mentally retarded.

The nurse may find herself asked to be a member of a voluntary organisation that wishes to work for the mentally retarded, e.g. Down's Syndrome Association. She may be invited to speak about mental retardation with various groups e.g. church, service clubs, etc.

These are excellent opportunities to educate the public and stimulate their taking responsibility for the needs of the mentally retarded.

The nurse acts throughout as liaison officer, coordinating the services of the voluntary community organisations and those of the State.

\section{THE COMMUNITY NURSE'S ACTIVITIES IN CO. ORDINATION WITH THE MULTIDISCIPLINARY TEAM OF A CARE AND REHABILITATION CENTRE}

\section{PREVENTION OF MENTAL RETARDATION}

A. Health and Welfare professionals in the community need education regarding the prevention of mental retardation. The part that they can play in alleviating social, economic and emotional stress needs to be emphasised. This includes persons such as health visitors, paediatricians, general practitioners and social workers. Many do not consider, or are not aware, that even though they may not be able to deal with the problems themselves, there are specific agencies to whom they can refer their clients, e.g. psyciatric social workers, psychologists, mar- 
riage guidance counsellors, dietitian, genetic counsellors, remedial teachers.

"It is clearly recognised that the major problems of over three-quarters of the retarded are psychosocial in kind and thus call for educational and other psychologically based preventative modalities"'(5)

B. Where the nurse finds mental retardation in a family, she is able to refer clients to genetic counsellors, so that the risks of the mental retardation recurring may be assessed. This often alleviates much anxiety between married couples and those planning to marry.

C. Mental retardation may occur in children who grow up in an environment lacking stimulation and/or where there is mental and physical abuse.

Early intervention by means of family therapy and possible individual therapy, as well as a programme for stimulation and education in the home can be planned, implemented and evaluated by the multidisciplinary team.

D. Where physical defects that can be treated by medication or diet are detected e.g. cretinism and phenylketonuria, the nurse can ensure that parents understand how to maintain the treatment and are aware of the importance of keeping strictly to the prescribed regime.

\section{PROMOTION OF NORMALISATION}

In the past the mentally retarded were often placed in centres where they received custodial care. Today many of these persons are institutionalised, their potentials have not been developed and they have consequently lost the right to a normal life style. Their families have remained with feelings of guilt, which have often been the cause of their drifting away and losing contact.

Where families have kept their mentally retarded member at home, they have often had to endure pain and frustration in the absence of knowledgeable and constructive consultants catering to the needs of the entire family.

A family centred approach by the community nurse is therefore essential. She directs her tasks towards normalisation, for both the family and the mentally retarded individual.

Kay F. Englehardt states that normalisation for the nurse implies assisting persons to assume responsibilities for which they are competent.

This is often inhibited by the nurse's and other professionals' fear of taking risks, particularly because of professional liability.

Practitioners need to examine whether their fears are appropriate as well as to examine the possible conflict between their role as helpers and their role as promoters of the client's independence. ${ }^{(6)}$
A. The initial bonding of the mother with the mentally retarded newborn and the family's willingness to strive towards acceptance and accommodation of the child into their lives, is the first of many hurdles which parents have to overcome during the progressive life stages of the child and the family.

B. The nurse must take cognisance of the emotions of guilt, unrealistic hope and anger towards professionals which the parents might harbour.

The nurse counsellor must at the opportune moment allow the family to discuss and help plan the child's future. Parents often feel that professionals make all the decisions and that those are often unjustified.

Parents must be encouraged to discuss their own feelings. This mental catharsis of unburdening themselves is in itself beneficial.

An important support for parents is to have one agency to which they can turn at all times. The multidisciplinary team can offer this service. The team can evluate the total child in the context of this family. The final opinion is a coordinated one which can, if necessary, refer the client to an agency more suitable for dealing with a specific problem.

C. Professionals such as the family physician, paediatrician, gynaecologist or midwife, due to their uncertainty and discomfort when delivering a handicapped child, or meeting one at a consultation, are inadvertently the cause of a lifetime of unresolved conflicts for the parents and a consequent loss of opportunity for normalisation of the child.

Too often these professionals say "Put the child away", because of their own anxiety, without giving a thought to the needs of the child or his family.

It therefore remains for the nurse to interpret the concept of normalisation to other practitioners, so that adequate and effective service may be promoted.

"There is no longer a question that community programming and placement is preferable to residential care and treatment. Residential placement of any individual should be considered temporary and provided only under limited circumstances. There is nothing inherent to any degree of intellectual ability which, in itself, demands long-term commitment". (7)

D. Care and Rehabilitation for the Mentally Retarded Child in the Community.

(i) The mentally retarded child has a reduced ability for spontaneous exploration and play. This prevents the development of his already limited potential.

Parents must therefore be advised that the 
child needs active stimulation and repetitive experiences to a far greater extent than normal children. They need to be "taught" to play, as they often lack initiative and concentration. The parents in turn, need to be taught how to use play for training and recreation.

Toy libraries are very useful in this respect. Parents can be advised in respect of and loaned the correct toys for the advancement of the level of functioning of the child. The task becomes simpler for the parents, when they are shown that the mentally retarded child needs the same play experiences as the normal child, only his abilities to master the activity will take longer and at times may never be achieved.

The child at home has a mother figure to bond with, an essential prerequisite for normal psychosocial development.

At home that child has more chance of receiving indiviaual attention from consistent figures, from whom he learns verbal and non-verbal communication. Another example of the numerous advantages of individual care is the provision of correct food consistencies and methods of feeding for the individual child, which is important for speech development as well as independence not to mention the opportunity for the child to feed himself!

The mentally retarded child is often a great mimic. How important for him then, to be surrounded by normal people!

In an institution these opportunities are remote. It is the Department of Health's policy that no child under the age of 3 years should be admitted to a Care- and Rehabilitation Centre except for medical reasons. ${ }^{(8)}$

(ii) The Nurse may initiate and encourage parents to join parent groups or social clubs for the mentally retarded and their families.

Here parents meet others like themselves. They can talk freely about themselves and their children. This gives them tremendous support and they are often able to give each other practical help and advice.

Where the mentally retarded accompany their parents or where there are special clubs for the mentally retarded without their parents, they have an all important opportunity to mix socially, particularly with the opposite sex, make new friends and participate in a variety of activities. (iii) The mentally retarded child will need assessment at various intervals in his life. This can be co-ordinated and monitored by the multidisciplinary team who can then assist parents with further planning.

Surgery may be indicated for e.g. squints, harelip, contractures, dental treatment.

A physiotherapist can, for example, give treatment for muscle co-ordination for increased mobility, can assist in the use of prostheses, or advise and treat for the prevention of contractures.

A psychiatrist may need to prescribe or adjust medication for seizures, hyperactivity or depression.

A psychologist can investigate behaviour problems and advise on a behaviour modification programme.

Sibling problems, when they occur, are often caused by parental attitudes.

Puberty is often a stressful period during which the family require counselling.

Sexual activity in the mentally retarded, is that of the normal individual. The mentally retarded needs to be taught the socially acceptable norms, if not, he may exhibit behaviour which causes the family and the community anxiety. Depo-Provera contraceptive injections for females and vasectomy in special cases for males can alleviate anxiety about unwanted pregnancy and thus allow more freedom of movement for the mentally retarded.

Assessment by an occupational therapist, teacher or psychologist can provide guidance for further developmental training or educational programmes as well as for placement in work and community living situations.

Social circumstances may need to be investigated by the social worker. Government grants may need to be applied for, as these parents have an extra financial burden due to medical fees, special medical aids, extra clothing and line, home help, additions and alterations to the home, etc.

Speech therapy may be indicated to facilitate coherent speech, as incoherent speech restricts social contact, job opportunities, as well as causing frustration for the individual.

(iv) Nursery schools have today been established by voluntary bodies.

They are willing to take children as soon as they can walk, as they realise the importance of an early start with an intensive training 
programme before the child develops bad habits due to lack of stimulation and discipline, such as poor concentration and self-mutilation.

Often parents are encouraged to spend time at the nursery school so that they can reinforce the training at home. Some mentally retarded children can be placed in normal nursery schools with a sympathetic teacher. Normal peers provide excellent stimulation in these circumstances.

As the child progresses and becomes of school age, an assessment is made regarding further education, based largely on psychological tests.

In the Republic of South Africa special classes in some normal schools, under Provincial Administration exist for those in the I.Q. range 50 - 70 .

Successful pupils from the primary special classes may be selected for special secondary schools, where they are given a practical education. These schools fall under the Provincial Administration.

The Department of National Education provides schools for children with specific disabilities e.g. Vista Nova, Cape Town, for cerebral palsy and learning disabilities and the School for the Blind and Deaf, Worcester, Cape Province.

These schools cater for normal as well as special classes.

Training centres are provided by the Department of National Education for children with I.Q.'s ranging between 30 - 50 e.g. OASIS, Alta du Toit, Sunnyday Centre for Cerebral Palsy, Cape Town.

Day care for those who are regarded as untrainable (I.Q. below 30) is at present provided by voluntary organisations, e.g. Friends School at Alexandra Care and Rehabilitation Centre, Cape Town. This caters for young children where a structured day with learning experiences is provided so that any possible potential may be developed.

Once past school age i.e. 18 to 21 , ability again determines the suitability of the individual for work at sheltered employment or protective workshops provided by the Welfare Section of the Department of Health, Welfare and Pensions or work on the open market.

(v) The Hospital or Care and Rehabilitation Centre remains a community resource. Here the Ward Sister joins the multidisciplinary team. It should not be used as a dumping ground, but for very specific needs and only rarely as a permanent measure.

(a) In cases where there is a great deal of nursing care and constant medical attention needed.

(b) Where home circumstances are unfavourable and detrimental to the health and welfare of the mental retardate and no other suitable accommodation can be found.

(c) Admission may be required for assessment, e.g. for behaviour problems, establishing a training programme or for assessment for future planning.

(d) Temporary admission, so that parents can have a holiday, or in time of crisis, is a service which is greatly appreciated by families.

(e) Orphaned individuals with no one to care for them, need to be admitted until suitable accommodation can be found e.g. in a hostel or with a landlady.

(vi) The Community Nurse is active in the rehabilitation of those residents who have had years of institutionalisation.

(a) Family involvement needs to be reactivated by showing the family what their help means.

(b) Social training in areas outside the institution can be done by the nurse or voluntary workers can be organised to visit residents, take them on outings, show them places of interest, take them shopping, acquaint them with public transport and places of entertainment, etc. However, it is extremely difficult to find voluntary workers who are prepared to commit themselves to this kind of work.

(c) Landladies with whom the residents may live, must be sought in the community.

(d) Prospective employers need to be canvassed in order to find suitable work for discharged residents.

(vii) For those rehabilitated residents, discharged and living in the community, the nurse has the task of looking after their health and welfare. This task is usually shared by the welfare agency responsible for administering the disability grants which they live on.

The community nurse needs to wean them 
from institutional care to resources such as day hospitals and dental clinics and teach them how to spend their leisure time, by introducing them to suitable social clubs and organisations.

Management of their day to day affairs can be monitored by the community nurse, at an appropriate distance. Some may be living together and managing the household by themselves. Assistance and supervision can be given regarding budgeting, planning and preparation of meals, division of labour, the settling of interpersonal conflicts, physical health and their employment

Frequently there is initial stress as a result of the adjustment to this community living. Psychosomatic illnesses and depression may manifest themselves. Treated with care and understanding and assisted by medication, when appropriate, these symptoms soon disappear, particularly as those discharged become more familiar with their new life, and their acquaintances and activities become increasingly broader and broader, much to their delight and increase in self-esteem.

After-care groups are an excellent opportunity for ex-residents to meet each other and the nurse. Problems can be discussed in which they can learn from each other.
Constructive criticism, counselling, encouragement and praise can be given, all of which are an essential part of an after-care service.

Mental retardation in the Republic of South Africa is emerging from the doldrums.

Today it is established as part of psychiatry, and psychiatry is very much a part of mental retardation. As with psychiatry, treatment is a joint venture between the client and the health care team, requiring hard work from both.

The challenges, the opportunities, the stimulation and the rewards are all waiting to be had by any nurse who pauses long enough to look at what mental retardation care has to offer while for the mentally retarded, once they are regarded as "people with handicaps", not "handicapped people", there is the hope of a happier future for them and their families.

\section{REFERENCES}

1. Owens G. and P. Birchenall: Mental Handicap: The Social Dimensions. London, Pitman, 1979, p.7

2. Ibid, p.8

3. lbid, p. 188

4. Hannam, C.: Parents and Mentally Handicapped Children. London, Pelican Books, 1975. 5. Menolascino, F.J.: Psychiatric Approaches to Mental Retardarion. New York, Basic Books Inc. 1970.

6. Curry, J.B. and K.K. Peppe: Mental Retardation - Nursing Approaches to Care. St Louis, C.V. Mosby Company, 1978.

7. Primrose, D.A.A.: Proceedings of the Third Congress of the International Association for the Sctentific Study of Mental Deficiency. Volume I The Hague, Netherlands, Polish Medical Publishers, 1973.

8. Department of Health; Criteria for the Admission of Mental Retardates to State Institutions and Licensed Homes. 